\title{
CORRELATION OF THE ENGLISH FAIRY TALE'S PLOT STRUCTURE AND ITS PROSODIC ORGANISATION
}

\author{
Larysa Taranenko \\ National Technical University of Ukraine "Igor Sikorsky Kyiv Polytechnic Institute”, Kyiv, Ukraine \\ litera@i.ua
}

In the paper on the basis of a systemic analysis of the English fairy tales' semantic, functional and structural characteristics the author updates its definition of a small form folk text, outlines typical genre characteristics and substantiates a hierarchical subordination of its functional features. The paper also advances the algorithmic model, representing the steps of unfolding the English fairy tales' plot elements, which serves as a theoretical and methodological ground for the experimental phonetic study of prosodic means that organise the text of a fairy tale. Within the process of model formation, the author performs a matrix analysis of the fairy tale's content and compositional structure, presented as a systemic algorithmic scheme. The evaluation of emotional and pragmatic potentials of the spoken fairy tale made it possible to describe the peculiarities of prosodic features functioning within its structural elements (exposition $\rightarrow$ development of the events $\rightarrow$ climax $\rightarrow$ denouement) and at their junctures as well as substantiate its invariant and variant intonation patterns. The carried out auditory analysis proves that there is a direct correlation between the fairy tale's plot structure and its prosodic means, whose specific interaction triggers creative and cognitive processes in the recipient's mind aimed at conveying the text pragmatic aim.

Keywords: English fairy tale; pragmatic aim; plot development; structural elements; algorithmic model; auditory analysis; prosodic means; invariant and variant prosodic patterns.

\section{Introduction}

One of the areas in the field of current text linguistics studies is prosodic characteristics of a spoken text. As is known (Pennington, 1996), prosodic phenomena constitute an important source of information on the text type, specificity of its segmentation, connotative and pragmatic meanings, etc. Thus, it is quite natural that text intonation is gaining its recognition not only in the sphere of linguistics, but also in language teaching as an integral part of students' language fluency, competence and proficiency.

In view of this, we have focused our interest on the study of fairy tales. In terms of its text size and content of its structural elements the fairy tale is an original epic work, which accumulates the ancestral centuries-old folk wisdom, being the very factor that has already resulted in revealing the fairy tale distinctive features and still leads to unfolding its new unique properties. One of such characteristics was observed by Propp (2001), who stated that fairy tales are rather similar in their structure (p. 24) and suggested using this fact while searching for a new approach to the classification of fairy tale's features.

The cited approach, based on an integrated study of algorithmic structures of textual plots and their semantic content, was tested on the material of English fables (Taranenko, 2008, pp. 36-42). The results of the approach application proved the potential possibility to solve the current problem of establishing the correlation between the plot elements and synergistic processes of folk texts self-development (Kalyta \& Taranenko, 2013, pp. 174-175) as well as specificity of their prosodic organisation.

Considering these ideas, in the paper we have undertaken a substantiation of the invariant algorithmic pattern of the English fairy tales' structure based on the analysis of their plot development, which can serve as a theoretical and methodological ground for the experimental phonetic study of the fairy tales' prosodic characteristics.

\section{Methodological stipulations as to the study of fairy tale's plot structure}

\subsection{Defining the characteristic features of the fairy tale as a folk genre}

The fairy tale as one of the most popular genres of oral epic tradition has been studied by linguists rather thoroughly. It is significant that the emergence of folkloristics as an academic discipline is largely associated with the research of fairy tales. In general, the study of fairy tales took shape in the XIX-XX ${ }^{\text {th }}$ centuries within various scientific fields, represented by Wilhelm and Jacob Grimm, Theodor Benfy, Johannes Bolte in Germany, Paul Sébillot, Joseph Bédier, Pierre Saintyves in France, Alexander Afanasyev, Alexander Veselovsky, Vladimir Propp in Russia and others (Haase, 2008, pp. 135, 360-361).

A significant contribution to solve the issue of tales systematisation was made by the Finnish scholar Antti Aarne, who in 1910 published a classification of tale types. That very year in Helsinki Kaarle Krohn established the International Folklore Fellows' group, whose reports as well as indexes of tale types of different nations were published for many years in Folklore Fellows' Communications (Nikoljukin, 2001, pp. 989-994). 
Thus, due to thorough studies conducted within that approach there appeared the Aarne-Thompson classification system of fairy tales "Index of the Types of the Folktale" (1928), i.e. the classification system developed by Antti Aarne and enlarged by the American folklorist Stith Thompson. Its second edition is commonly referred to as the "tale-type index" (also known as the "AT index", or the "Aarne-Thompson index") (Aarne, 1961). The AT index was further expanded in 2004 by the German folklorist Hans-Jörg Uther. The folklorists now refer to tale types by their ATU numbers (Haase, 2008, p. 361). In addition to this index, many folklorists around the world compiled tale-type indexes of stories told in their own regions (see, for instance, "The index of fairy stories based on Aarne's system" by N. Andreyev (Andreyev, 1929), "A comparative index of Eastern Slavic tales" (Barag et al., 1979), etc.). The scope of steadily growing research into fairy tales was also evident in the "Encyclopedia of fairy tales", whose publication was launched in 1975 by Kurt Ranke (Nikoljukin, 2001, pp. 989-994).

It should be noted that at present scholars continue searching for different kinds of fairy tales indexes, their classifications and other theoretical formations which can serve as a ground for registering the data on archetypal, common and differential elements or features of the diversity of multinational fairy tales. At the same time there still remain unsolved issues on the generalised definition of the fairy tale as a folk genre and systematisation of its chief functions. So we see it reasonable to perform a brief analysis of the scholar's views on the fairy tale definition and its functional characteristics.

According to Propp, the fairy tale, being based on fiction (Propp, 1998, p. 29), differs from all other stories in its special poetics (Propp, 2000, p. 24). Thus, the genre of a fairy tale should be regarded as a folk bélles-léttres (Propp, 1998, p. 283).

A number of other scholars found it useful to outline the fairy tale's main characteristics by contrasting it with the legend. Jacob Grimm suggested the following criterion for their differentiation: "the fairy tale is more poetic, the legend is more historical" (Zipes 2002, p. 167). Generations of folklorists elaborated on the Grimms' observation and further specified the differences between tale and legend as two basic forms of narration related to each other by a shared body of motifs and episodes but standing in opposition to one another (Haase, 2008, p. 487).

Dégh (1982) remarked that these two forms correspond to primary attitudes in human culture so they can merge and blend into each other (pp. 58-59). Luthi wrote that fairy tales and legends as two basic forms of narration due to their lasting coexistence can both be assumed as manifestations of basic needs of the human psyche (cited in Dégh, 1982). These views are complemented by formal characteristics given to these genres by Bascom (1965), who noted that folk tales, legends and myths, unlike proverbs, riddles, tonguetwisters and other forms of verbal art, should be termed "the prose narratives" (p. 3).

The stated above ideas indicate the necessity to search for more specific features, differentiating the fairy tale from legend and myth. In this regard we should mention, first of all, that fairy tale, being similar to myth in its idealised representations, is based, unlike myth, on the facts of real existence of people and their societies. Thus, we believe that the approximation of the fairy tale's plot to real events should be considered as its dominant feature. Secondly, just as the legend, the fairy tale, relying on real events, is formed on the basis of idealised representations, but differs from the legend in its significantly lower degree of ideological influence and a higher degree of artistic imagery and poetics.

Speaking about the fairy tale's basic characteristics, it is interesting to point that the creation of genetically oldest fairy tales, as is known (Pomeranceva, 1971, p. 881), goes back to the pre-class society, which over time liberated itself from redundant elements of mythological thinking. In the course of its formation as a genre the fairy tale was inevitably accumulating international archetypal plots that reflect historical and environmental conditions of various peoples and nationalities (Nikoljukin 2001, pp. 989-994).

In scientific literature we can also come across a number of other features, pertaining to the fairy tales, namely: conventionality of its plot structure and compositional elements, contrastive grouping of characters, lack of detailed descriptions of nature and family life (Grom'jak et al., 2007, p. 321), specific humour and friendly irony (Propp, 2000, p. 228), concentration of information and regulation of its amount, presentation of people's ideals and views on good and evil (Pomeranceva, 1971, p. 881) and so on.

As a result of the comparative analysis of the fairy tale features, we have formulated its generalised definition. Thus, the fairy tale should be regarded as a didactic epical poetic story of oral folk art, aimed at satisfying the basic world-view needs of the human psyche by means of accumulating in its plot the archetypal ideas of primordial folk wisdom, that are highlighted in the story against the background of a controversial struggle between the good and the evil, and which comes to its utopian happy end due to some fictional events or the character's magic acts.

It follows from the definition that the main function of the fairy tale is a didactic one. At the same time, one can claim that the fairy tale has a polyfunctional nature, reflected in its ability to perform such functions as historic, aesthetic (Propp, 1998, p. 89), cognitive, moral, ethical, social, educational, entertaining 
(Grom'jak et al., 2007, p. 321), ideological, therapeutic (Zipes, 2002, pp. 19, 175, 350) and of subliminal influence (Cherepanova, 1999, p. 219).

We believe that all these functions are the sub-functions of the fairy tale, realising its basic didactic function. Thus, the system of the fairy tale functional characteristics acquires the following hierarchical sequence: general didactic function $\rightarrow$ every-day-life-culture pragmatic orientation $\rightarrow$ socio-educational role.

\subsection{The analysis of scientific views on the fairy tale's compositional structure}

A significant stimulus to the study of the fairy tale's compositional structure came from the classification of 25 thousand folk tales according to their genre varieties known as the Aarne-Thompson or the Aarne-Thompson-Uther tale-type index by A. Aarne, S. Thompson and H.-J. Uther.

Thus, Kerbelyte (2001) created a structural and semantic classification of Lithuanian folk tales, differentiated by their basic plots. A somewhat different aspect of the fairy tale structure was presented by Veselovsky (1989), who described algorithms of the story development from its motif to the plot (pp. 300306). Similarly, Volkov (1924) classified fairy tales according to their fifteen major story-lines (e.g., about a hero-the-fool, three brothers, a wise girl, etc.) and proposed to consider them as a permanent unit of the fairy tale semantic analysis.

As a result of the "morphological analysis" of fairy tales, Nikiforov (2008) formulated the following three laws of their compositional construction: the repetition of dynamic elements of the fairy tale, the existence of a compositional focal point of events and a categorial or grammatical formation of fantastic actions. In addition, he singled out invariants of the schematic development of the story events (pp. 314-318).

A special interest in terms of the considered problem presents the work by Propp (2001, pp. 26-59). Having analysed the fairy tale plots, the author differentiated thirty-one functions, to which he referred the character's deeds or actions in the course of plot deployment. However, it is difficult, in our opinion, to agree with such a usage of the term "function" since, being a general scientific causative-consecutive category (Il'chev et al., 1983, p. 751), it means in this case the explicit or latent goal, which determines the progression of characters' actions. Moreover, as a result of the semantic analysis of proposed functions we can qualify the majority of them (without distorting the essence of the author's views) as plot elements of the fairy tale story-line.

An equally interesting idea was expressed by Greimas (1985), who tried to reduce Propp's functions to a less complex structure that simplifies the description of the fairy tale episodes (p. 91). As a result, he distributed functions into pairs and reduced their number to twenty episodic units (e.g.: "prohibition violation", "trap - assistance", "struggle - victory", "punishment - the wedding", etc.). We consider the attempt to simplify the fairy tale plot units as a methodologically justified approach. At the same time, we cannot totally share the results obtained by Greimas, because in some cases he violated the known dialectical principle of contrasting the opposites which are equal in rank and nature. Thus, he juxtaposed episodic units having different degrees of generalisation or significance. For instance, instead of "prohibition - violation" it would be logical to unite the episodes into the pair "prohibition - permission", or we would suggest using the paired episodes "punishment - reward", instead of "punishment - the wedding", etc.

In his turn, Andreyev (1929), in the process of compiling his index of fairy tales on the bases of Aarne's system, groups them into three main classes: tales about animals, fairy tales proper and anecdotic tales with their further differentiation within each class. What is worth mentioning is that at the lowest hierarchical level of fairy tale's distinctive features systematisation Andreyev interpreted their plots by summarising the elements of their story-lines development (for instance, a fox falls on the road, pretending to be dead; the man puts it on the cart; it throws the fish off the cart and jumps off).

Summarising the mentioned ideas, we can state that amid the extensive data generated and practically obtained by linguistics there are basic theoretical principles and concrete empirical facts that allow us to form a generalised algorithmic-and-structural pattern of the story-line development of the English fairy tales.

\section{Defining the algorithmic pattern of English fairy tales \\ 3.1. The sequence of methodological actions}

Following the outlined ideas, we have made an attempt to substantiate the invariant algorithmic pattern of the English fairy tales' structure based on the analysis of their story-lines development. To solve the task we opted for an integrated approach to the study of algorithmic structures of fairy tales' story-lines and their content, which was tested on the material of English fables (Taranenko, 2008, pp. 36-42).

Before starting the search for the fairy tale's algorithmic pattern, we should clearly differentiate the two basic notions of our analysis, i.e. "the plot" and "the story-line". Thus, we understand "the plot" as the algorithm of events that shape the story-line, while "the story-line" is a way of accounting the fairy tale's theme according to certain plot elements (Taranenko, 2008, p. 39). 
While developing research methodology of the undertaken study we substantiated the expediency of carrying out its three steps. It was rational within the first step to search for a certain systemic model that comprises main structural components of the fairy tale story-line, due to which its structure can be viewed as a functional hierarchical system of elements with their inherent linkage and relations. The second step presupposed a concise formulation of the plot elements' content. The essence of the third step lied in the formation of a matrix, directly reflecting the connection of structural components of the English fairy tales with the semantic content of their plot elements.

\subsection{Results of the conceptual analysis of the fairy tale structure}

On the basis of the outlined sequence of methodological actions we formed a hierarchy of the English fairy tales' structural components and plot elements. This allowed us to systematise structural elements into the algorithmic model presenting the development of the English fairy tale story-line according to its plot elements (see Fig. 1).

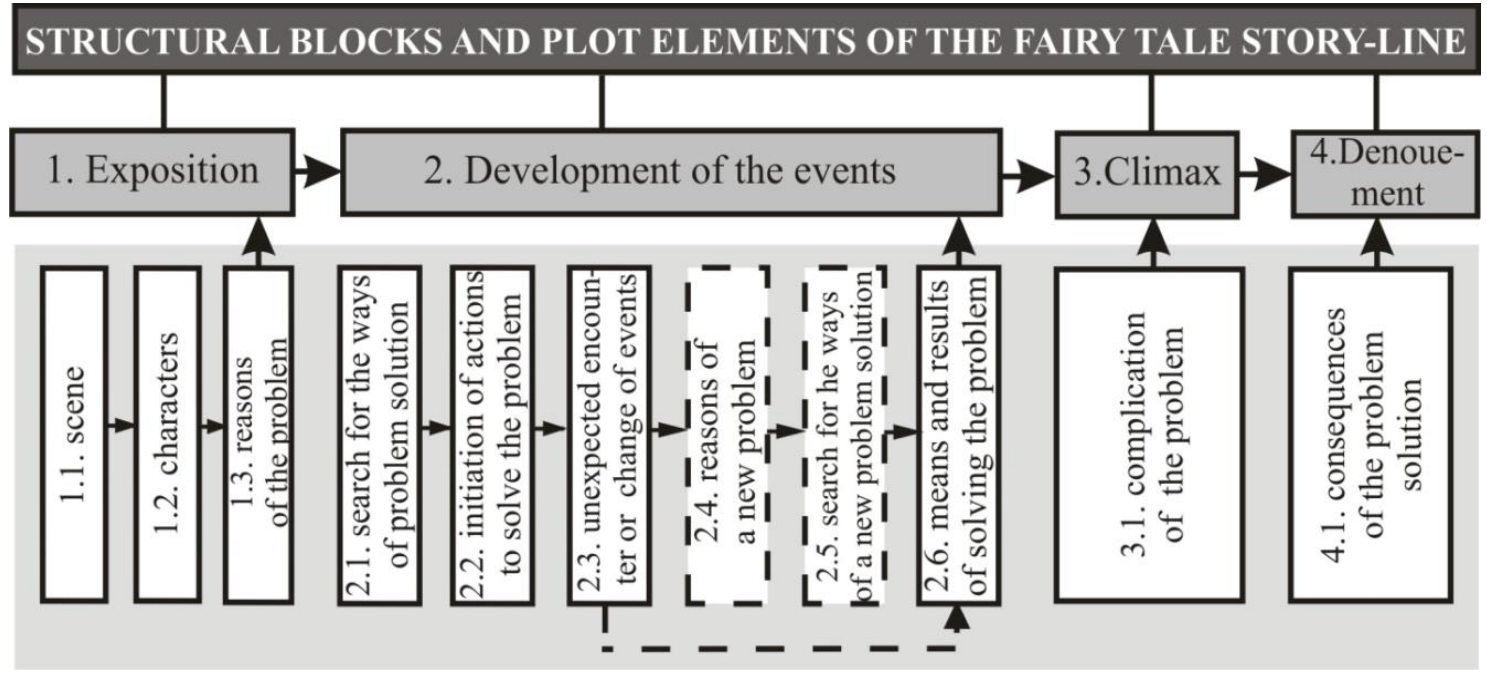

Fig. 1. Algorithmic pattern of the fairy tale story-line development according to its plot elements

The first level of the systemic model introduces the following structural blocks of the fairy tale storyline: exposition, development of the events, climax, denouement. Further division of these blocks into plot elements enabled us to determine the nature of each of them viewed as a set of a lower hierarchical level of the considered model. A verbal representation of the pattern of the development of English fairy tales' storyline is as follows: 1) exposition: 1.1. scene, 1.2. characters, 1.3. reasons of the problem; 2) development of the events: 2.1. search for the ways of problem solution, 2.2. initiation of actions to solve the problem, 2.3. unexpected encounter or change of events, 2.4. reasons of a new problem, 2.5. search for the ways of a new problem solution, 2.6. means and results of solving the problem; 3) climax: 3.1. complication of the problem; 4) denouement: 4.1 . consequences of the problem solution.

The algorithmic sequence of actions that ensure the story-line development is marked on the model (Fig. 1) with arrows of a corresponding direction. Thus, for the formation of the fairy tales' "exposition" as a separate structural block with its plot elements according to the complete algorithmic pattern the author is supposed to enclose the following elements in their strict sequence: 1.1. scene $\rightarrow 1.2$. characters $\rightarrow$ 1.3. reasons of the problem. In case of applying one of the alternative reductions of the fairy tale algorithm, the plot-algorithmic elements 1.1 or 1.3 or both of them can be omitted.

In contrast, the algorithm of the plot elements, comprising the structural block "development of the events" is considerably more complex. According to the results of our analysis, in the vast majority of the English folk tales this compositional block is formed according to a minimal algorithm, which embraces a successive realisation of such plot elements as: 2.1 search for the ways of problem solution $\rightarrow 2.2$ initiation of actions to solve the problem $\rightarrow 2.3$ unexpected encounter or change of events $\rightarrow 2.6$ means and results of solving the problem. However, there are fairy tales whose stories have an additional emergence of problems. In order to describe the ways of their overcoming, after the presentation of the plot element 2.3 the story-line successively introduces the elements 2.4 - reasons of a new problem and 2.5 - search for the ways of a new problem solution. Such an emergence of a new problem can be repeated twice within the progression of plot elements of the compositional block "development of the events" and is described with the same algorithm used for depicting a single problem occurrence. 


\subsection{Results of the analysis of the content of fairy tale's structural blocks}

As it was outlined in methodological stipulations of the given research, its third step presupposes formation of a matrix, directly reflecting the connection of structural components of the English fairy tales with the semantic content of their plot elements.

As a result of this step realisation, we formed a matrix which summarises the content of algorithmic plot elements that form the structural blocks of English fairy tales' story-line, presented in Table 1.

The vertical column of Table 1 reflects the structure and content of the system shown in Fig. 1. The horizontal heading of the table includes information about the existing variability of the plot elements content obtained as a result of the analysis of English fairy tales, including the page reference of their most comprehensive publication (Jacobs, 1890).

Table 1

The matrix presenting the content of the algorithmic plot elements that form the structural blocks of English fairy tales' story-line

\begin{tabular}{|c|c|c|c|}
\hline \multicolumn{2}{|c|}{$\begin{array}{l}\text { Story-line } \\
\text { structural } \\
\text { components }\end{array}$} & $\begin{array}{l}\text { Algorithmic plot } \\
\text { elements }\end{array}$ & CONTENT OF THE PLOT ELEMENTS \\
\hline \multirow{6}{*}{ 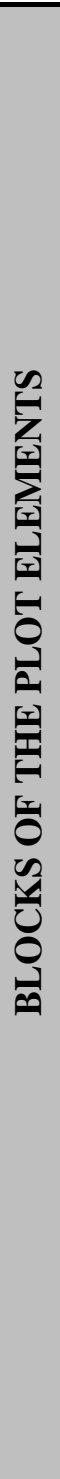 } & \multirow{3}{*}{ : } & 1.1. Scene & $\begin{array}{l}\text { Close to reality: county }(131,155) \text {, territory }(51,61,137,155) \text {, } \\
\text { country (77), locality }(66,74) \text { etc.; } \\
\text { Unreal/fantastic: vinegar bottle }(34), \text { etc. }\end{array}$ \\
\hline & & 1.2. Characters & $\begin{array}{l}\text { People: aristocracy }(15,37,103,117,131,137,141,155) \text {, } \\
\text { married couples }(24,34,66,144) \text {, childless married couples }(103) \text {, } \\
\text { mother and son(s) }(53,98,113) \text {, mother/father and daughter }(19,48, \\
117) \text {, grandma }(30) \text {, soldier }(41) \text {, peasant }(77) \text {, woman }(51,109,148) \text {, } \\
\text { boy }(32,122,127,145) \text {, etc.; } \\
\quad \text { Animals: bears }(74) \text {, pigs }(30,59) \text {, cats }(136) \text {, mice }(63,136) \text {, } \\
\text { etc.; birds: chicken }(87) \text {, magpie }(140) \text {, etc.; } \\
\quad \text { Fairy or miraculous creatures: sorcerer/wizard/fairy }(61,89, \\
\text { 137, 154), giant }(37,77) \text {, house spirit (144), Tom Thumb (113), etc. }\end{array}$ \\
\hline & & $\begin{array}{l}\text { 1.3. Reasons of the } \\
\text { problem }\end{array}$ & $\begin{array}{l}\text { Outer reasons: misunderstanding between the characters }(19,24 \text {, } \\
48,145) \text {, having nowhere to live }(34,41) \text {, lack of food }(53,74,94 \text {, } \\
122) \text {, change of circumstances }(30,98,109,144,155) \text {, unexpected } \\
\text { event }(37,89,114,117,131,148) \text {, etc.; } \\
\text { Inner reasons: character's imprudence (in actions, forecasts, } \\
\text { behaviour, etc.) }(61,98,140) \text {, ignorance }(37,66,87) \text {, incapability } \\
\text { (137), foolishness }(61), \text { love }(117,131) \text {, envy }(27,133,141,150) \text {, } \\
\text { hatred }(27,150) \text {, fear }(77,136) \text {, laziness }(113) \text {. }\end{array}$ \\
\hline & \multirow{3}{*}{ 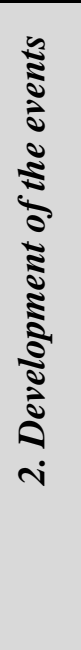 } & $\begin{array}{l}\text { 2.1. Search for the } \\
\text { ways of problem } \\
\text { solution }\end{array}$ & $\begin{array}{l}\text { External influence: to take advice }(131) \text {, to undertake a task or } \\
\text { respond to demand (19,77,89, 94, 98, 136, 141, 148); } \\
\text { Inner-motivated solution: to improve the financial situation }(34,53 \text {, } \\
\text { 113, 122), to destroy the enemy (77), rival }(141,150) \text {, to get married (19, } \\
98,117) \text {, to see the world }(24,32,66) \text {, to find happiness (145), to change } \\
\text { the state of affairs }(61,137,156) \text {, to get rich (53), etc. }\end{array}$ \\
\hline & & $\begin{array}{l}\text { 2.2. Initiation of } \\
\text { actions to solve the } \\
\text { problem }\end{array}$ & $\begin{array}{l}\text { Made the first step: followed the advice (131), built smth (58), set off } \\
(24,51,87,122,141,155) \text {, killed }(27,43) \text {, cheated or lied }(37,48,53 \text {, } \\
61,117,137) \text {, robbed (41), got hired (113), bought smth (30), etc. }\end{array}$ \\
\hline & & $\begin{array}{l}\text { 2.3. Unexpected } \\
\text { encounter or change of } \\
\text { events }\end{array}$ & $\begin{array}{l}\text { The acquaintance with real or fairy characters: strangers }(24) \text {, } \\
\text { passers-by }(30,41) \text {, fellow-travellers }(32,87,122,150) \text {, cut-throats } \\
\text { (32), giants }(53,94,98) \text {, animals }(87,150) \text {, wizards }(61,89,103) \text {, etc. } \\
\text { The change of real or fairy events and circumstances: falling in } \\
\text { love }(37,48) \text {, acquiring a magic item }(53,98,145,155) \text {, getting the } \\
\text { unexpected help }(131,155) \text {, transformation }(48) \text {, somebody's birth } \\
\text { (37), death }(102,109) \text { or unexpected survival }(137) \text {, etc. }\end{array}$ \\
\hline
\end{tabular}

(continued) 
Table 1(continued)

The matrix presenting the content of the algorithmic plot elements that form the structural blocks of English fairy tales' story-line

\begin{tabular}{|c|c|c|}
\hline & $\begin{array}{l}\text { 2.4. Reasons of a new } \\
\text { problem }\end{array}$ & $\begin{array}{l}\text { The desire of further enrichment }(53,102) \text {, satisfaction of } \\
\text { additional needs }(32,41,148) \text {, occurrence of new hardships }(19,30 \text {, } \\
37,66,87,94,98,117,137) \text {, etc. }\end{array}$ \\
\hline & $\begin{array}{l}\text { 2.5. Search for the } \\
\text { ways of a new problem } \\
\text { solution }\end{array}$ & $\begin{array}{l}\text { The change of action logic }(19,103,141) \text {, persuasion (37), } \\
\text { submission to the existing circumstances (154), the choice of } \\
\text { comfortable conditions (103), etc. }\end{array}$ \\
\hline & $\begin{array}{l}\text { 2.6. Means and results } \\
\text { of solving the problem }\end{array}$ & $\begin{array}{l}\text { Achieving the goals with the help of: friends (98), wife/sweetheart } \\
\text { (37, 150), fellow-travellers }(30,43,136,150) \text {, slyness or craft }(41,53) \text {, } \\
\text { luck }(19,103,113,120,122) \text {, intelligence }(27,48,98,141) \text {, experience } \\
\text { (24), courage }(109) \text {, charm }(19,43,66,131,145) \text {, etc. } \\
\text { Failure to achieve the goal by reason of: foolishness }(34,63,87 \text {, } \\
\text { 114, 154), greediness }(51,102,137,155) \text {, etc. }\end{array}$ \\
\hline 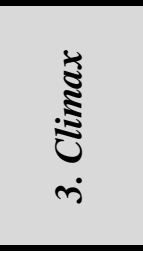 & $\begin{array}{l}\text { 3.1. Complication of } \\
\text { the problem }\end{array}$ & $\begin{array}{l}\text { Expected: getting conceived }(19,32,41,94,117,144) \text {, avoiding } \\
\text { threat or punishment }(27,53,61,98,120) \text {, getting punishment }(34 \text {, } \\
58,74,94,114,154) \text { or reward }(32,141,150) \text {. } \\
\text { Unexpected: escaping threat or punishment }(53,87) \text {, finding out } \\
\text { the truth }(24,43,48,109) \text {, unexpected good deed/ event }(87,103 \text {, } \\
113,122,144) \text {, or punishment }(51,63,148) \text {. }\end{array}$ \\
\hline 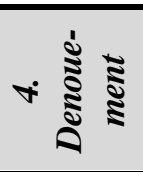 & $\begin{array}{l}\text { 4.1. Consequences of } \\
\text { the problem solution }\end{array}$ & $\begin{array}{l}\text { Positive: well-being }(30,32,53,103,117,122,137) \text {, marriage } \\
(24,37,48,77,94,113,145,155), \text { threat or danger disappearance } \\
(19,27,61,87,109,144) \text {, etc. } \\
\text { Negative: left with nothing }(34,43,63,74,102,148,154) .\end{array}$ \\
\hline
\end{tabular}

We are to remark here that due to the restrictions of the table presentation format we have included only brief general formulations of plot elements semantic content. In addition, for an adequate understanding of the presented in matrix material the alternative content components of such plot elements as 1.1 "scene", 1.2 "characters", 1.3 "reasons of the problem" are marked by nouns, since actions or events are not as a rule described in exposition of the fairy tale. On the contrary, in all other plot elements of the fairy tale structural blocks (development of the events, climax and denouement) the content is reflected with the help of the verbs that represent the characters' actions.

Under these conditions, we obtain a possibility to make a further direct transition from generalised formulations of plot elements presented in Table 1 to the expanded presentation of their specific meanings in texts (Jacobs, 1890) of the English fairy tales.

The carried out research confirmed the existence of a typical algorithmic pattern of the fairy tale storyline, which can serve as a methodological basis for conducting the auditory analysis of the fairy tales' prosodic organisation.

\section{Results of the auditory analysis of English fairy tales' prosodic organisation}

The auditory analysis was performed in compliance with a theoretically justified and practically verified (Kalyta \& Taranenko, 2012, pp. 186-191) postulation concerning the rationality of performing a description of prosodic patterns representing dynamic changes of the text emotional and pragmatic potential within its algorithmic plot elements. Besides, our study was aimed at revealing prosodic means' functional specificity at the juncture of adjacent plot elements and compositional blocks as well as at climatic elements of fairy tales, which, according to Kalyta (2001, pp. 191-193), should acquire the nature of prosodic universals.

Thus, in the course of analysis we registered typical prosodic patterns common for the outlined above compositional blocks of the fairy tales. The considered prosodic patterns included length of pauses at the block juncture, distribution of utterance stress, types of terminal tone and scale, pitch and voice range fluctuations in each block. In order to specify the peculiarities of the fairy tale prosodic organisation attention was also given to loudness, tempo as well as voice quality modifications.

It has been established that there is a correlation between the type of a structural block and prosodic means organising it. Thus, in the analysed fairy tales, the exposition is characterised by a great number of perceptive pauses which acquire emphatic colouring and prepare a listener for an incipient conflict, revealing where and when the events take place, who the characters are, what circumstances have brought them together and what reasons will bring the problem, e.g.: 
'Once $u^{\bullet}$ pon a ,time | there was a woman, | and she 'baked $\uparrow$ five pies. $\|$ And ${ }^{\mid}$when they ${ }^{\prime}$ came 'out of the oven, | they were ${ }^{\prime}$ that ${ }^{\circ}$ overbaked $\xi$ the 'crusts $\xi$ were $\left.\right|_{\text {too }}$ 'hard to eat (Jacobs, 1890, p. 19).

The auditory analysis of exposition proves that initial syntagms have the same prosodic organisation irrespective of their lexical or grammatical presentation. Specifically, syntagms which begin with a stressed syllable are high- pitched having low-rising, mid- or low-falling terminal tones (e.g.: 'Once upon a ,time...; IOne day..., etc.), while the syntagms with the unstressed syllable(s) at their beginning are pronounced at mid or low pitch in combination with low-rising, mid- or low-falling terminal tones (e.g.: There $\left.\right|_{\text {was an }}{ }^{\bullet}$ old ,soldier...; There ${ }^{\prime}$ once ${ }^{\bullet}$ lived $a{ }^{\mid}$king and a queen... etc.). The initial syntagms of the other compositional blocks are marked by a heightened pitch with the lowering tendency towards the end. The tempo of exposition is usually realised from moderate to slowed-down zones within final syntagms in order to prepare the listener for the development of further events.

The beginning of the block development of the events is marked similarly to all the compositional components of the fairy tale by a long pause, while pauses that occur at its plot elements' junctures are rather short. This creates a certain dynamics of the communicative progression within each plot element.

The first plot element of the development of the events describes the character's search for the ways of problem or conflict solution. Syntagms, introducing this plot element, contain, as a rule, direct speech, which is typically pronounced with a level terminal tone of low or mid pitch, what makes the listener feel anxious

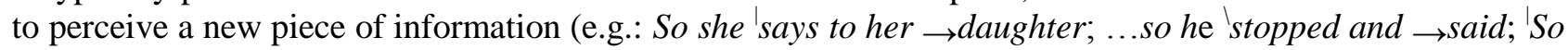
he dis,mounted $\mid$ and went , up to him and $\rightarrow$ said..., etc.).

The following plot element outlines circumstances initiating the character's actions to solve the problem. Consequently, it is marked by the highest degree of various fluctuations of intonation parameters creating the atmosphere of anticipation of further events. For instance, speech acquires dynamics due to its delimitation into short syntagms, the use of falling tones in non-final syntagms, combination of several kinetic tones within a syntagm, widened voice range as a result of high falling tones with a slowed down or accelerated rate of their movement, a high frequency of perceptive pauses. The interaction of all mentioned prosodic means help the listener focus on the upcoming information within the development of the fairy tale events.

By reason of its didactic nature the overall tempo of the fairy tale is rather moderate. Unlike this tendency, the tempo of the plot element presenting an unexpected encounter of the main character or sudden change of events is somewhat accelerated which helps express the emotional colouring and dynamics of the narration. Moreover, this plot element stands out with the emphatic use of intonation contours, in particular with the actualisation of broken descending stepping and regular descending sliding heads accompanied with the emphatic use of terminal tones, e.g.:

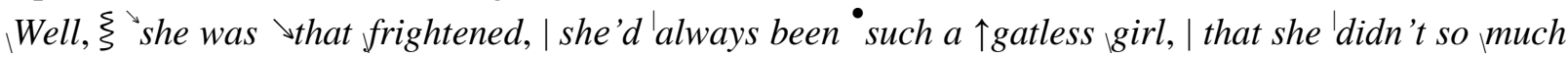

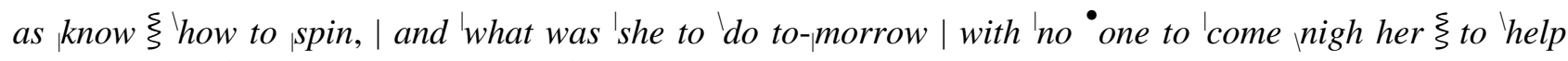
her? \|| She $\left.\right|_{\text {sat }} ^{\bullet}$ down on a stool in the $\bullet^{\bullet}$ kitchen, | and 'law! how she 'did |cry! || (Jacobs, 1890, p. 20).

The intonation of the final plot element of the analysed block is also preconditioned by its semantic content that presents the character's deeds as well as the means of problem solution. Besides, its intonation is characterised by emotiveness conditioned by the anticipation of the fairy tale's climax. Thus, the development of its events is defined by modifications of tempo from moderate to accelerated or from moderate to slowed-down and variations in pitch (high / low) and range (wide / narrow) of nuclear tones in the adjacent syntagms.

Prosodic arrangement of the climax corresponds to its functional essence as a point of the highest tension of a story-line. Due to its functionality it is marked by a high frequency of short syntagms consisting only of two stressed syllables. If syntagms are longer, usually each notional word in them is under stress (i.e. they have approximately the same degree of stress since all of them are equally important, e.g.: ${ }^{\text {That }}$ was I grinning from $\uparrow$ ear to ear). Such a distribution of stress favours to comprehend the climax as highly tense and rhythmical. The lexical units which convey semantically most significant and weighty information are perceived as highlighted with the help of emphatic perceptive pauses and contrasted pitch intervals preceding them, the use of accidental rises as well as high falling tones with the slow rate of movement. In final syntagms of this compositional block the voice range is narrowed and the tempo is somewhat slowed down. Thus, the prosodic organisation of the climax may be regarded as an effective means of revealing both the emotional information of the fairy tale and its didactic value.

The beginning of the denouement, which is designed to convey logical consequences of the problem solution as well as to render the didactic idea of the whole text, is also marked by a long pause. Due to its concluding nature, the tempo varies from moderate to decelerated. The syntagms of the denouement have similar intonation patterns, i.e. they are differentiated by prosodic parallelism. Another common feature of the 
analysed block is that irrespective of lexical and grammatical means of its organisation, it is pronounced with less variable intonation contours, the gradually descending stepping, broken and checked heads being most frequent, e.g.:

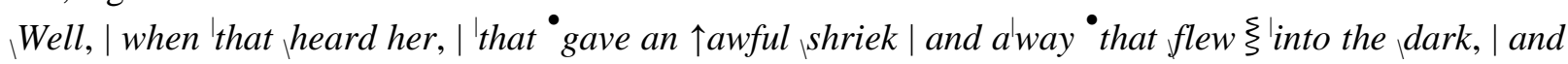
she $\left.\right|_{\text {never }}$ saw it $\xi$ any more $\|$ (Jacobs, 1890, p. 24).

It is also a typical feature of this block prosodic pattern to have a prevailing low falling terminal tone, which expresses a generalising inferring of the characters' deeds described in a fairy tale as well as performs the socio-instructive function. Thus, the interaction of prosodic means within the denouement serves to sum up the outcome of the problem raised in the fairy tale.

The results of the auditory analysis prove that the specificity of fairy tales' prosodic organisation enables the listener to perceive the information, focusing on its important parts. The interplay of contrasted, or opposed parameters of melodic, dynamic and temporal prosodic subsystems predetermined by the fairy tale compositional structure and its semantic context, favours the attraction of the listener's attention to the fairy tale's pragmatic aim and didactic value.

\section{Conclusions}

The conducted theoretical substantiation and practical testing of the offered algorithmic pattern of the fairy tale plot development can be used as a basis for an integrated fairy tales' classification able to serve as theoretical and methodological grounds for the scientific analysis of any aspect of their creation and functioning.

The outcome of the auditory analysis verifies that the fairy tale is characterised by a specific prosodic arrangement of its structural blocks. The prosodic parameters may be regarded as the effective means of delimiting the fairy tale into compositional blocks and conveying its pragmatic aim.

We believe that the presented results can reveal to linguists virtually unlimited prospects for comprehensive computerised modelling of any complete scientific classification of functional and linguistic features of various nations' fairy tales as well as can serve as the basis for the formation of training programs for creating literary fairy tales.

\section{References:}

Aarne, A. (1961). The Types of the Folktale: a Classification and Bibliography. Translated and enlarged by S. Thompson. Helsinki: Academia Scientarum Fennica.

Andreyev, N. (1929). Ukazatel' skazochnyh sjuzhetov po sisteme Aarne [The index of fairy stories based on Aarne's system]. Leningrad: Gos. russk. geographicheskoje obshhestvo.

Barag, L. Berezovskij I., Kabashnikov K. \& Novikov N. (1979). Sravnitel'nyj ukazatel' sjuzhetov. Vostochnoslavjanskaja skazka [A comparative index of Eastern Slavic tales]. Leningrad: Nauka.

Bascom, W. (1965). The Forms of Folklore: Prose Narratives. The Journal of American Folklore, 78(307), 3-20. https://doi.org/10.2307/538099

Cherepanova, I. (1999). Dom koldun'i. Jazyk tvorcheskogo bessoznatel'nogo [The sorceress' house. The language of creative unconscious]. Moscow: KSP+.

Dégh, L. (1982). Folk Narrative. In Folklore and Folklife, edited by Richard M. Dorson, 53-83. Chicago, London: The University of Chicago Press.

Greimas, A.J. (1985). V poiskah transformacionnyh modelej [In search of transformational models] In Zarubezhnye issledovanija po semiotike fol'klora [Foreign research of folklore semiotics] (pp. 89-109). Moscow: Nauka.

Grom'jak, R. T., Kovaliv, Ju. I. \& V. I. Teremok (Eds). (2007). Literaturoznavchyj slovnyk-dovidnyk [Literary referential dictionary]. Kyiv: Vydavnychyj centr "Akademija".

Haase, D. (Ed). (2008). The Greenwood Encyclopedia of Folktales and Fairy Tales. Westport, Connecticut, London: Greenwood Press.

Il'chev, L., Fedoseev P., Kovalev S. \& Panov V. (Eds). (1983). Filosofskij jenciklopedicheskij slovar' [Philosophic encyclopedic dictionary]. Moscow: Sovetskaja jenciklopedija.

Jacobs, J.(Ed.). (1890). English Fairy Tales. London: David Nutt.

Kalyta, A. (2001). Fonetychni zasoby aktualizacii' smyslu anglijs'kyh emocijnyh vyslovljuvan' [Phonetic means actualizing the meaning of an English emotional utterance]. Kyiv: Publishing center of Kyiv National Linguistic University.

Kalyta, A., \& Taranenko L. (2012). Perceptivna j instrumental'na ocinki emocijno-pragmatichnogo potencialu vislovlen' [Auditory and instrumental evaluation of the utterance emotional-and-pragmatic potential] Naukovij visnik Volins'kogo nacional'nogo universitetu imeni Lesi Ukrä̈nk. Serija: Filologichni nauki: Movoznavstvo, 24 (249), 186-191.

Kalyta, A. \& Taranenko L. (2013). Generalized Model of the Genesis of Literary Genres. Humanities and Social Sciences Review, 2(2), 171-175.

Kerbelyte, B. (2001). The Types of Folk Legends: The Structural-Semantic Classification of Lithuanian Aetiological, Mythological, and Historical Legends. Saint Petersburg: Evropeyskiy Dom.

Nikiforov, A. (2008). Skazka i skazochnik [Fairy tales and story-tellers]. Moscow: OGI.

Nikoljukin, A. N.(Ed). (2001). Literaturnaja jenciklopedija terminov i ponjatij [Literary encyclopedia of terms and notions]. Moscow: NPK "Intelvak".

Pennington, M.C. (1996). Phonology in English Language Teaching. London: Longman. https://doi.org/10.4324/9781315843872 
Pomeranceva, E. (1971). Skazka [The fairy tale] In A. A. Surkov (Ed.) Kratkaja literaturnaja jenciklopedija (Concise literary encyclopedia), (Vol. 6, pp. 880-882). Moscow: Sovetskaja jenciklopedija.

Propp, V. (1998). Pojetika fol'klora. Sobranie trudov V.Ja. Proppa [Poetics of folklore. Collected works by V. Propp]. Moscow: Labirint.

Propp, V. (2000). Russkaja skazka: Sobranie trudov V.Ja. Proppa [A Russian fairy tale. Collected works by V.Ja. Propp]. Moscow: Labirint.

Propp, V. (2001). Morfologija volshebnoj skazki [Fairy tale's morphology]. Moscow. Labirint.

Taranenko, L. (2008). Prosodychna zv'jaznist' anglijs'koi' prozovoi' baky [Prosodic cohesion of an English prosaic fable]. Kyiv: TOV "Agentstvo "Ukrai'na".

Veselovskij, A. (1989). Istoricheskaja pojetika [Historical poetics]. Moscow: Vysshaja shkola.

Volkov, R. (1924). Skazka velikorusskaja, ukrainskaja, belorusskaja [A Russian, Ukrainian, Belorussian fairy tale] In Skazka. Razyskanija po sjuzhetoslozheniju narodnoj skazki (The fairy tale. A search for the plot structure of a folk tale). Vol. 1. Odessa: Gosudarstvennoje izdatelstvo Ukrainy.

Zipes, J. (Ed). (2002). The Oxford Companion to Fairy Tales. Oxford: Oxford University Press. https://doi.org/10.1093/acref/9780198605096.001.0001

Received: March 24, 2017

Accepted: May 25, 2017 
